\title{
FREQUENCY IN CORPORA AS A SIGNAL OF LEXICALIZATION (ON THE ABSOLUTE USAGE OF COMPARATIVE AND SUPERLATIVE ADJECTIVES)
}

\author{
PAVLA KOCHOVÁ
}

Czech Language Institute of Czech Academy of Sciences, Prague, Czech Republic

\begin{abstract}
KOCHOVÁ, Pavla: Frequency in corpora as a signal of lexicalization (on the absolute usage of comparative and superlative adjectives). Journal of Linguistics, 2019, Vol. 70, No 2, pp. $148-157$.
\end{abstract}

Abstract: The study deals with the category of comparison of Czech adjectives from the semantic point of view; it concentrates especially on the so-called absolute (or elative) usage of comparatives and the absolute usage of superlatives and their lexicographic treatment (or absence of the lexicographic treatment) in Czech monolingual dictionaries. The question is whether their frequency in corpora can prove lexicalization of this usage.

Keywords: corpus linguistics, corpus lexicography, dialect corpora

\section{STARTING POINTS}

\subsection{The status of the adjective gradation in the language description}

It is a well-known fact that in the language description the gradation of adjectives stands between inflection (morphology) and derivation (word-formation). This has been clearly expressed in [11]. J. Panevová [18], [19] presents a brief overview of arguments both for morphology and for word-formation and notes that descriptions in various grammar handbooks of the Czech language differ: the Grammar of Czech (Mluvnice češtiny) from 1986 treats gradation differently in different places - in the first volume as part of word-formation [5, pp. 378-380, 448-49] and in the second volume as part of morphology [14, pp. 79-80]; the Handbook of Czech Grammar (Príruční mluvnice češtiny [12, pp. 176-180, 222] and the handbook Czech - Speech and Language ( ̌́eština - řeč a jazyk [4, pp. 132$133,141]$ consider the comparative and the superlative to be part of word-formation, in contrast to the Grammar of Contemporary Czech (Mluvnice současné češtiny [3, pp. 205-209] and the Academic Grammar of Contemporary Czech (Akademická gramatika současné češtiny [21, pp. 380-385, 503-507], which consider them to be part of morphology. Concerning the lexicographic treatment, in Czech monolingual academic dictionaries, i.e. the Reference Dictionary of the Czech Language (Přriruční slovnik jazyka českého [8]), the Dictionary of the Standard Czech Language (Slovník spisovného jazyka českého [7], hereinafter SSJČ), the Dictionary of Standard Czech 
for Schools and the General Public (Slovnik spisovné češtiny pro školu a veřejnost [6], hereinafter SSČ), the Academic Dictionary of Contemporary Czech (Akademický slovník současné češtiny, hereinafter ASSČ), as well as commercial dictionaries, i.e. the Internet Dictionary of Contemporary Czech (Internetový slovník současné češtiny [10], hereinafter ISSČ), comparatives are listed as part of grammatical information, e.g. the comparative vétši 'bigger' is listed in the entry for vel(i)ký 'big' - mainly because it is an irregular comparative form. ${ }^{1}$ In a similar way the comparative lepši 'better' is listed in the entry dobry' 'good', at the same time it is treated as a separate entry - due to the lexicalization of the absolute (elative) usage of this comparative form. ${ }^{2}$ The "grammatical" treatment of comparatives is probably related to the space limitations of the dictionary. The formation of comparative (and superlative) forms and their semantic structure are very regular; therefore, there are usually no lexicographic reasons for their special description.

It is evident that the absolute usage of comparative (or superlative) forms should be taken into consideration by lexicographers. As [1], [18], [19], [13] $]^{3}$, and grammar handbooks (see [14, pp. 79-80]; [21, pp. 383-384]) indicate, there exists an asymmetry between the form (comparative) and its function (non-comparative, absolute usage), ${ }^{4}$ i.e. comparative and superlative forms are used without explicit comparison. Some of these occurrences could be considered as their "regular" comparative usage - although comparison is not explicitly expressed - because the comparative aspect is more or less obvious (implicit comparison with the average or usual value is present) (see [18], [19]).

\subsection{Treatment of lexicalized comparatives and superlatives in monolingual dictionaries}

This fact influences the number of registered comparative (or superlative) forms with a lexicalized meaning, i.e. those that are listed in monolingual dictionaries. Surprisingly, the number of registered comparatives which are treated as a lexical unit (i.e. not only as adjective morphological forms) is very low. In the SSČ there are lexemes lepši 'better', vyšši 'higher', menšs 'smaller', starš̌ 'older', horši 'worse', nižši 'lower', mladši 'younger', bližši 'closer', dřivěǰš $i^{5}$ 'earlier', pozdějši 'later',

\footnotetext{
${ }^{1}$ Superlative forms are not usually listed because of their regularity.

${ }^{2}$ On the treatment of gradation of adjectives (and adverbs) in the ASSČ (and in other existing Czech monolingual dictionaries), see [20].

${ }^{3}$ See the entries Stupňování (P. Karlík), Elativ (Z. Hladká) and Komparativ and Superlativ (both entries by K. Osolsobě).

${ }^{4}$ The absolute usage is usually analysed for comparative forms ([18], [19]; [21]); [1], [14], [13] (in the entry Superlativ) mention it for superlative forms as well.

${ }^{5}$ The comparative status of the form dřivejšs (allegedly belonging to the positive form brzký 'early') was questioned in [13, Komparativ]. Nevertheless in the Internet language handbook (Internetová jazyková príručka [9]), in [3], and in the ASSČ it is registered as a comparative for the lemma brzký.
} 


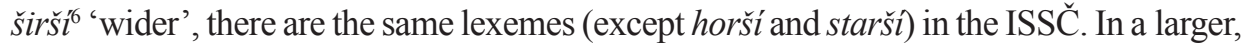
but older dictionary (SSJČ) we find only lexemes lepši , menší, starší, mladší, pozdějš́, dřivějsší, bližšl dictionary, ${ }^{8}$ but in the Dictionary of the Contemporary Slovak Language (Slovnik súcasného slovenského jazyka, hereinafter SSSJ) we can find the superlative adjective forms najbližši 'the closest, the nearest', najmenši 'the smallest', which are listed as separate lexical units; the treatment of some adjectives in the positive form indicates the lexicalization of some other superlative forms, e.g. drahy' 'dear'. Entries for superlative forms najhorši 'the worst', najlepši 'the best', najsvätejši 'the most holy', and najvy̌šsi 'the highest' are listed because they form phraseological and multi-word units.

\section{ADJECTIVE GRADATION IN THE LATEST LEXICOGRAPHIC DESCRIPTION OF CZECH}

\subsection{Adjective gradation from the frequency point of view}

It is a well-known fact that gradation applies to a small part of adjectives for semantic and formal reasons. In [3, p. 205] it is presented that only $6 \%$ of adjectives have graded forms, in [17, p. 21] the proportion is indicated to be $8 \%$ (i.e. 5440 lemmas of 65400 adjective lexemes in the most complete corpus then, in 2010). In the corpus SYN2015 adjectives with comparative or superlative forms make up 5\% of all adjectives. ${ }^{9}$ The above-mentioned distinctions lie in different corpus sources that were used. As it was pointed out, the possibility of the adjective gradation is related to semantics.

Commonly, qualitative adjectives create comparative and superlative forms, relational (classifying) adjectives do not. From a different point of view, the occurrence of these forms within the category of (originally) classifying adjectives indicates semantic changes. Therefore, in the ASSČ (started in 2012) comparative forms are registered in all adjective entries where comparatives are commonly used (the same principle is used in the SSSJ); this information has two functions - to indicate the correct form and to signal the semantic type of the adjective.

At the same time, gradable adjectives occur in comparative and superlative forms quite rarely. Experts from the Institute of the Czech National Corpus were

${ }^{6}$ It is not listed as a separate entry but it is registered within the entry for široký 'wide'; it is placed in the sense 'relating to as many people as possible from a certain field' with the comment "often širši (without comparison)" and with the examples pořady pro široký, širši okruh posluchačũ; výstava pro širokou veřejnost; zboži široké spotreby 'programs for a wide, wider audience; an exhibition for the general public; goods of wide consumption'.

${ }^{7}$ It is registered within the entry blizký in the sense "detailed, elaborate" with the comment "only the comparative".

${ }^{8}$ Only in the ISSČ lexicalized nouns from superlative adjective forms are registered - nejmenši 'very young child', nejhorši 'the worst alternative'.

${ }^{9}$ The methodology of determining this number was similar to that of [17, pp. 20-21]. 
asked to make a list of adjectives that are commonly used in comparative and superlative forms. ${ }^{10}$ The list contains units that have an absolute frequency of at least 10 in the corpus SYN2015, and at the same time appear in their graded forms, i.e. comparatives and superlatives together, at least in $20 \%$ of their occurrences. The list is quite short, including the adjectives with suppletive comparatives and superlatives (i.e. dobrý 'good', lepší, nejlepší; velký 'big', větší, největšíi, malý 'small', menší, nejmenši; špatný 'bad', horši nejhorší; dlouhý 'long', delši, nejdelší; brzký 'early', dřivějšsi, nejdřivějši i).

\begin{tabular}{|c|c|c|c|c|c|c|c|c|}
\hline & Lemma & $\begin{array}{l}\text { Comparative } \\
+ \text { superlative } \\
\text { forms } \\
\end{array}$ & & Lemma & $\begin{array}{l}\text { Comparative } \\
+ \text { superlative } \\
\text { forms } \\
\end{array}$ & & Lemma & $\begin{array}{l}\text { Comparative } \\
+ \text { superlative } \\
\text { forms } \\
\end{array}$ \\
\hline 1 & velký 'big, great' & 72053 & 31 & př́sný 'strict' & 1023 & 61 & vytížený ‘busy' & 104 \\
\hline 2 & dobrý 'good' & 55740 & 32 & podrobný 'detailed' & 1019 & 62 & prozaický 'prosaic' & 93 \\
\hline 3 & vysoký ‘high’ & 38906 & 33 & pomalý ‘slow’ & 998 & 63 & $\begin{array}{l}\text { povolaný } \\
\text { 'qualified' }\end{array}$ & 91 \\
\hline 4 & malý 'small' & 25034 & 34 & mocný 'powerful' & 866 & 64 & $\begin{array}{l}\text { markantní } \\
\text { 'striking' }\end{array}$ & 77 \\
\hline 5 & starý 'old' & 23701 & 35 & závažný ‘serious’ & 860 & 65 & $\begin{array}{l}\text { odrostlý 'grown- } \\
\text { up' }\end{array}$ & 76 \\
\hline 6 & špatný 'bad' & 14382 & 36 & $\begin{array}{l}\text { rozšířený } \\
\text { 'widespread' }\end{array}$ & 855 & 66 & $\begin{array}{l}\text { sdílný } \\
\text { 'communicative' }\end{array}$ & 55 \\
\hline 7 & nízký ‘low’ & 13764 & 37 & tmavý ‘dark’ & 784 & 67 & $\begin{array}{l}\text { smiŕlivý } \\
\text { ‘conciliatory' }\end{array}$ & 55 \\
\hline 8 & mladý 'young' & 12300 & 38 & početný 'numerous' & 512 & 68 & hořejší 'top, upper' & 53 \\
\hline 9 & dlouhý 'long' & 9540 & 39 & $\begin{array}{l}\text { prodávaný 'best- } \\
\text { selling' }\end{array}$ & 509 & 69 & roztodivný 'odd' & 45 \\
\hline 10 & \begin{tabular}{|l|} 
důležitý \\
'important' \\
\end{tabular} & 9229 & 40 & zazšsi 'later' & 409 & 70 & $\begin{array}{l}\text { vroucný ‘fervent, } \\
\text { dear' }\end{array}$ & 41 \\
\hline 11 & $\begin{array}{l}\text { blízký ‘near, } \\
\text { close' }\end{array}$ & 8290 & 41 & vlivný 'influential' & 407 & 71 & $\begin{array}{l}\text { sebenepatrný } \\
\text { 'slight' }\end{array}$ & 41 \\
\hline 12 & silný 'strong' & 6439 & 42 & $\begin{array}{l}\text { produktivní } \\
\text { 'productive' }\end{array}$ & 371 & 72 & $\begin{array}{l}\text { žádoucný } \\
\text { 'desirable' }\end{array}$ & 36 \\
\hline 13 & široký 'wide' & 5290 & 43 & žádaný ‘desired' & 347 & 73 & $\begin{array}{l}\text { obsažný } \\
\text { 'comprehensive' }\end{array}$ & 33 \\
\hline 14 & pozdní 'late' & 4300 & 44 & $\begin{array}{l}\text { navštěvovaný } \\
\text { 'visited' }\end{array}$ & 274 & 74 & obsazovaný 'cast' & 32 \\
\hline 15 & $\begin{array}{l}\text { jednoduchý } \\
\text { 'simple' }\end{array}$ & 4168 & 45 & $\begin{array}{l}\text { šetrný 'friendly } \\
\text { [environmentally], } \\
\text { thrifty' }\end{array}$ & 258 & 75 & fajnový 'fine' & 32 \\
\hline 16 & rychlý 'fast' & 4008 & 46 & $\begin{array}{l}\text { hodnotný } \\
\text { 'valuable' }\end{array}$ & 247 & 76 & $\begin{array}{l}\text { benevolentní } \\
\text { 'benevolent' }\end{array}$ & 28 \\
\hline
\end{tabular}

${ }^{10}$ We express our thanks to Dominika Kovárííková and Václav Cvrček. 


\begin{tabular}{|c|c|c|c|c|c|c|c|c|}
\hline & Lemma & $\begin{array}{l}\text { Comparative } \\
+ \text { superlative } \\
\text { forms }\end{array}$ & & Lemma & $\begin{array}{l}\text { Comparative } \\
+ \text { superlative } \\
\text { forms }\end{array}$ & & Lemma & $\begin{array}{l}\text { Comparative } \\
+ \text { superlative } \\
\text { forms }\end{array}$ \\
\hline 17 & levný ‘cheap’ & 3955 & 47 & \begin{tabular}{|l} 
sofistikovaný \\
'sophisticated'
\end{tabular} & 230 & 77 & $\begin{array}{l}\text { vyznamenávaný } \\
\text { 'honour'd' }\end{array}$ & 26 \\
\hline 18 & krátký 'short' & 3798 & 48 & chutný 'tasty' & 218 & 78 & $\begin{array}{l}\text { stahovaný } \\
\text { 'downloaded' }\end{array}$ & 24 \\
\hline 19 & $\begin{array}{l}\text { drahý 'dear, } \\
\text { expensive' }\end{array}$ & 3694 & 49 & \begin{tabular}{|l} 
náchylný \\
'susceptible'
\end{tabular} & 202 & 79 & otužilý 'hardy' & 24 \\
\hline 20 & častý 'frequent' & 3433 & 50 & $\begin{array}{l}\text { frekventovaný } \\
\text { 'busy' }\end{array}$ & 175 & 80 & vzrušivý 'exciting' & 20 \\
\hline 21 & hluboký 'deep’ & 3387 & 51 & $\begin{array}{l}\text { př́hodný } \\
\text { 'appropriate' }\end{array}$ & 172 & 81 & $\begin{array}{l}\text { zavilý 'fierce, } \\
\text { ferocious' }\end{array}$ & 20 \\
\hline 22 & \begin{tabular}{|l|} 
složitý \\
'complicated, \\
complex' \\
\end{tabular} & 2963 & 52 & $\begin{array}{l}\text { vyhledávaný } \\
\text { 'sought' }\end{array}$ & 164 & 82 & $\begin{array}{l}\text { onaký 'another, } \\
\text { better' }\end{array}$ & 18 \\
\hline 23 & \begin{tabular}{|l} 
dříiějěši ‘earlier, \\
previous'
\end{tabular} & 2900 & 53 & lidnatý 'populous' & 162 & 83 & skladný 'compact' & 18 \\
\hline 24 & slabý 'weak' & 2815 & 54 & čtený 'read' & 135 & 84 & $\begin{array}{l}\text { obletovaný } \\
\text { 'adored' }\end{array}$ & 18 \\
\hline 25 & snadný 'easy' & 2495 & 55 & palčivý 'burning' & 131 & 85 & hovorný 'talkative' & 14 \\
\hline 26 & náročný 'difficult' & 2259 & 56 & výstižný 'concise' & 125 & 86 & $\begin{array}{l}\text { pregnantní } \\
\text { 'succint' }\end{array}$ & 14 \\
\hline 27 & \begin{tabular}{|l|} 
výhodný \\
'favourable, \\
advantageous'
\end{tabular} & 1537 & 57 & niterný 'inner' & 122 & 87 & $\begin{array}{l}\text { poslouchaný } \\
\text { 'listened to' }\end{array}$ & 11 \\
\hline 28 & \begin{tabular}{|l|} 
efektivní \\
'effective' \\
\end{tabular} & 1146 & 58 & \begin{tabular}{|l|} 
výnosný \\
'profitable'
\end{tabular} & 122 & 88 & křepký 'sprightly' & 10 \\
\hline 29 & účinný 'effective' & 1129 & 59 & důrazný 'strong' & 119 & 89 & první 'first' & 10 \\
\hline 30 & cenný 'valuable' & 1087 & 60 & schůdný ‘viable’ & 110 & 90 & & \\
\hline
\end{tabular}

Tab. 1. List of adjectives that are commonly used in comparative or superlative forms (in the corpus SYN2015).

Thirty of these adjectives were analyzed in more detail. Those were the adjectives with the biggest proportion of comparative forms among their total occurrences. The proportion of comparatives was chosen as the basic criterion because comparative forms are more often lexicalized (see above, 1.2). The same adjectives are sorted both by the proportion of comparatives (in the left part of the table) and by the proportion of superlatives (in the right part of the table). The list of them mostly contains the most frequent adjectives. It is obvious that a high proportion of graded forms among the occurrences of certain adjectives is conspicuous. Units with the biggest difference between the proportion of comparatives and superlatives are in bold type. 


\begin{tabular}{|c|c|c|c|c|c|c|c|c|c|}
\hline & Lemma & $\begin{array}{l}\text { Com- } \\
\text { para- } \\
\text { tives }\end{array}$ & $\begin{array}{l}\% \text { of } \\
\text { com- } \\
\text { para- } \\
\text { tives }\end{array}$ & $\begin{array}{l}\text { Total } \\
\text { frequency }\end{array}$ & & Lemma & $\begin{array}{l}\text { Super- } \\
\text { latives }\end{array}$ & $\begin{array}{l}\% \text { of } \\
\text { super- } \\
\text { latives }\end{array}$ & $\begin{array}{l}\text { Total } \\
\text { freque- } \\
\text { ncy }\end{array}$ \\
\hline 1 & brzký 'early' & 2900 & 77,81 & 3727 & 1 & blízký 'near, close' & 6175 & 34,66 & 17814 \\
\hline 2 & pozdní 'late' & 4276 & 60,33 & 7088 & 2 & častý 'frequent' & 2379 & 30,27 & 7858 \\
\hline 3 & nízký 'low' & 11081 & 42,70 & 25951 & 3 & dobrý 'good' & 29806 & 25,59 & 116490 \\
\hline 4 & levný 'cheap' & 2621 & 35,19 & 7448 & 4 & špatný 'bad' & 6298 & 20,69 & 30447 \\
\hline 5 & podrobný 'detailed' & 967 & 30,30 & 3363 & 5 & vysoký 'high' & 15781 & 20,09 & 78558 \\
\hline 6 & vysoký 'high' & 23125 & 29,44 & 78558 & 6 & levný 'cheap' & 1334 & 17,91 & 7448 \\
\hline 7 & špatný 'bad' & 8084 & 26,55 & 30447 & 7 & velký 'big, great' & 33233 & 17,38 & 191203 \\
\hline 8 & starý 'old' & 18439 & 25,81 & 71442 & 8 & důležitý 'important' & 6490 & 15,86 & 40918 \\
\hline 9 & $\begin{array}{l}\text { složitý 'complicated, } \\
\text { complex' }\end{array}$ & 2644 & 25,02 & 10566 & 9 & drahý 'dear, expensive' & 1544 & 13,55 & 11392 \\
\hline 10 & široký 'wide' & 4529 & 24,14 & 18760 & 10 & nízký 'low' & 2683 & 10,34 & 25951 \\
\hline 11 & slabý 'weak' & 2289 & 24,13 & 9488 & 11 & $\begin{array}{l}\text { výhodný 'favourable, } \\
\text { advantageous' }\end{array}$ & 456 & 9,03 & 5049 \\
\hline 12 & dobrý 'good' & 25934 & 22,26 & 116490 & 12 & efektivní 'effective' & 342 & 7,75 & 4413 \\
\hline 13 & snadný 'easy' & 2214 & 22,04 & 10045 & 13 & silný 'strong' & 2126 & 7,61 & 27923 \\
\hline 14 & $\begin{array}{l}\text { výhodný 'favourable, } \\
\text { advantageous' }\end{array}$ & 1081 & 21,41 & 5049 & 14 & rychlý 'fast' & 1265 & 7,49 & 16900 \\
\hline 15 & pomalý ‘slow' & 910 & 21,31 & 4270 & 15 & jednoduchý 'simple' & 1527 & 7,41 & 20617 \\
\hline 16 & velký 'big, great' & 38820 & 20,30 & 191203 & 16 & starý 'old' & 5262 & 7,37 & 71442 \\
\hline 17 & hluboký 'deep' & 2499 & 20,05 & 12461 & 17 & hluboký 'deep' & 888 & 7,13 & 12461 \\
\hline 18 & malý 'small' & 18864 & 19,72 & 95652 & 18 & malý 'small' & 6170 & 6,45 & 95652 \\
\hline 19 & mladý 'young' & 9643 & 19,68 & 48998 & 19 & slabý 'weak' & 526 & 5,54 & 9488 \\
\hline 20 & drahý 'dear, expensive' & 2150 & 18,87 & 11392 & 20 & mladý 'young' & 2657 & 5,42 & 48998 \\
\hline 21 & efektivní 'effective' & 804 & 18,22 & 4413 & 21 & náročný 'difficult' & 577 & 5,16 & 11182 \\
\hline 22 & dlouhý 'long' & 8130 & 16,98 & 47872 & 22 & krátký 'short' & 837 & 4,35 & 19236 \\
\hline 23 & rychlý 'fast' & 2743 & 16,23 & 16900 & 23 & široký 'wide' & 761 & 4,06 & 18760 \\
\hline 24 & silný 'strong' & 4313 & 15,45 & 27923 & 24 & dlouhý 'long' & 1410 & 2,95 & 47872 \\
\hline 25 & krátký 'short' & 2961 & 15,39 & 19236 & 25 & $\begin{array}{l}\text { složitý 'complicated, } \\
\text { complex' }\end{array}$ & 299 & 2,83 & 10566 \\
\hline 26 & náročný 'difficult' & 1682 & 15,04 & 11182 & 26 & snadný ‘easy' & 281 & 2,80 & 10045 \\
\hline 27 & častý 'frequent' & 1054 & 13,41 & 7858 & 27 & pomalý 'slow' & 88 & 2,06 & 4270 \\
\hline 28 & jednoduchý 'simple' & 2641 & 12,81 & 20617 & 28 & podrobný 'detailed' & 52 & 1,55 & 3363 \\
\hline 29 & blízký 'near, close' & 2115 & 11,87 & 17814 & 29 & pozdní 'late' & 24 & 0,34 & 7088 \\
\hline 30 & důležitý 'important' & 2739 & 6,69 & 40918 & 30 & brzký 'early' & 0 & 0,00 & 3727 \\
\hline
\end{tabular}

Tab. 2. List of thirty selected adjectives sorted by the proportion of comparatives (in the left part) and by proportion of superlatives (in the right part) in the total frequency. 


\subsection{Adjective gradation from the semantic point of view}

Concerning the lexicographic treatment, we are interested in comparative and superlative forms being used "absolutely", i.e. in examples without a general aspect of comparison (as pointed out above, comparison is not always explicitly expressed because of the occurrence of the average or usual value of the compared quality).

A high proportion of comparatives among the occurrences of a certain adjective suggests that the collocability of its comparative form compared with the collocability of both the positive form and the superlative form might need to be explored. The same should be done for superlative adjective forms, which need to be compared with both positive adjective forms and comparative forms. The collocability of positive, comparative and superlative forms with nouns is for some adjectives different (some examples see in C.2), for some adjectives identical (for some examples, see C.5).

The high proportion of comparative or superlative forms in Table 2 can be accounted for by:

(A) phraseological units:

- hlad je nejlepši kuchar̆ 'hunger is the best sauce'; cesta nejmenšího odporu 'the line of least resistance'; v nejhoršim př́padě 'at worst'; bližši košile než kabát 'blood is thicker than water'; je snadnějši uhlídat pytel blech, než... 'it's impossible to keep tabs on it'; je nejvy̌šši čas 'it's high time"'11,

(B) multi-word names (mainly terminological units):

- vyšši odborná škola 'higher vocational school', schi̊zka na nejvyšši úrovni 'toplevel meeting'.

These structures with comparatives and superlatives (in both (A) and (B)) must enter the lexicon as a unit. The comparatives or superlatives are not substitutable by the positive, or the substituted version loses its idiomaticity (see [18]). In a dictionary these lexical units need to be registered with definitions.

(C) There is other group of comparatives and superlatives used with a meaning which cannot express comparison. Some of them are already listed in Czech monolingual dictionaries as separate entries (see 1.2), but some are not. The difference between the meaning of the graded forms and the meaning of the positive typically results from different collocability. Sometimes the adjective-noun combination with a comparative or superlative has a meaning different from the common comparison, or the comparative or superlative meaning is neutralized. We find:

(C.1) terminological units in which a comparative (or superlative) form is repeated in a systematic way, i.e. comparative (or superlative) form is used in multi-word

\footnotetext{
${ }^{11}$ Phraseological units and their corpus detection and their exploration were not our concern.
} 
units of the same type. Some of the multi-word names can be registered within an "abstract" sense which associates (terminological) lexical units with similar meaning, e.g.:

- jitrocel větší, bedrník větší, vlaštovičník větší; citronik největší, líska největší (binomial botanical names);

- vyšši 'higher-level' with nouns rostliny 'plants', živočichové 'animals', organismy 'organisms', formy života 'forms of life'; jednodušš 'less complex' with nouns sloučeniny 'compounds', formy života; složitějšs 'more complex' with nouns látky 'substances', organismy;

- mladšilstarši žáci, mladši/starši dorostenci; nejmladši žáci (adjectives mladši 'younger', staršs 'older', nejmladši 'the youngest' in connection with nouns žáci 'pupils', dorostenci 'adolescents' express a well-defined age category);

- superlatives with different collocability compared with an adjective positive and comparative, e.g.: nejbližši 'the nearest / the earliest' collocates with the nouns príležitost 'opportunity', jednání 'negotiation', (možný) termín 'possible date' etc., the positive blizký and the comparative bližš $i$ are rare; similarly nejvyšš šstěstílblaho 'absolute happiness/welfare';

- the same with comparatives, e.g.: hlubši 'deeper' collocates with the nouns význam 'meaning', smysl 'sense', analyza 'analysis' etc., the comparative form is the most frequent (the positive hluboky' and the superlative nejhlubši are rare);

- superlative and positive forms can collocate with the same nouns, different from comparative forms, e.g. nejdražši 'the dearest' collocates with prittel 'friend' and with family member nouns (rodiče 'parents', maminka 'mum', tatinek 'dad'), and is thus similar in collocability to the positive drahý but different from the comparative dražší; nejhlubši 'the deepest' collocates with úcta 'reverence', soustrast 'condolence'; noc 'night', tajemstvi 'secret', nitro 'heart', and is thus similar in collocability to the positive form, but different from the comparative form;

(C.3) comparatives which are used in the euphemistic way:

- slabši povaha 'a weaker man', slabši zdravi 'rather poor health'; má silnějši postavu 'he/she is rather fat'; nejsem už nejmladši 'I'm not that young';

(C.4) comparatives which are very frequently used absolutely and their meaning is lexicalized in a "terminological" way, e.g. kratšsi 'not long', delši 'not short' - kratšil delši vlasy, na kratšildelši vzdálenosti. ${ }^{12}$

(C.5) A big number of graded forms are not indicative of semantic changes. The collocability of positive, comparative and superlative forms is also similar, e.g. collocability of podrobný 'detailed', podrobnějši , and nejpodrobnějšs is basically the

${ }^{12}$ In C.1 - C.4 we list mainly examples of lexicalized comparatives or superlatives which are not yet registered in Czech monolingual dictionaries. 
same - among the ten most frequent noun collocates are informace 'information', popis 'description', zpráva 'message', and vyšetřeni 'examination'.

We propose that the examples listed in C.1 - C.4 need to be registered in monolingual dictionaries. This can be done in several ways (in a separate entry, in the exemplification section by means of an additional definition or by a comment relating to limited collocability), according to conceptual principles of the particular situation.

\section{CONCLUSION}

This paper deals with the treatment of lexicalized comparative and superlative forms in Czech monolingual dictionaries, which appears insufficient. We look for corpus signals providing clear evidence of the lexicalization of absolute comparatives or superlatives. High frequency of these forms can indicate idiomaticity and semantic changes. However, the most prominent signal for lexicalization assessment of a comparative or superlative adjective is its collocability.

\section{References}

[1] Buzássyová, K. (1979). Príspevok k vymedzeniu neutralizácie v kategórii stupňovania. Jazykovedný časopis, 30(1), pages 6-17.

[2] Buzássyová, K. ( $1^{\text {st }}$ and $2^{\text {nd }}$ volumes) and Jarošová, A. (1 $1^{\text {st }}, 2^{\text {nd }}$ and $3^{\text {rd }}$ volumes) (eds.) (2006, 2011, 2015). Slovník súčasného slovenského jazyka. A - G. [1 ${ }^{\text {st }}$ volume]. H - L. [ $2^{\text {nd }}$ volume]. $\mathrm{M}-\mathrm{N} .3^{\text {rd }}$ volume]. Bratislava, Veda.

[3] Cvrček, V. et al. (2010). Mluvnice současné češtiny 1. Jak se píše a mluví. Praha, Karolinum.

[4] Čechová, M., Dokulil, M., Hlavsa, Z., Hrbáček, J., and Hrušková, Z. (2011). Čeština - řeč a jazyk. $3^{\text {rd }}$ revised edition. Praha, SPN - pedagogické nakladatelství, a. s.

[5] Dokulil, M., Horálek, K., Hůrková, J., and Knappová, M. (eds.) (1986). Mluvnice češtiny 1. Fonetika. Fonologie. Morfonologie a morfemika. Tvoření slov. Praha, Academia.

[6] Filipec, J., Daneš, F., Machač, J. ( $1^{\text {st }}$ edition), and Mejstř́ik, V. ( $2^{\text {nd }}$ and $3^{\text {rd }}$ edition) (eds.) ( $1^{\text {st }}$ edition, 1978; $2^{\text {nd }}$ revised edition, 1994; $3^{\text {rd }}$ revised edition, 2003): Slovník spisovné češtiny pro školu a veřejnost. Academia, Praha. [CD-ROM] (1997, 2004, 2005). Voznice, LEDA.

[7] Havránek, B., Bělič, J., Helcl, M., Jedlička, A., Kř́istek, V., and Trávníček, F. (eds.) (1960 - 1971). Slovník spisovného jazyka českého. Praha, Nakladatelství.

[8] Hujer, O., Smetánka, E., Weingart, M., Havránek, B., Šmilauer, V., and Získal, A. (eds.) (19351957). Příruční slovník jazyka českého. Praha, Státní nakladatelství, Školní nakladatelství, Státní pedagogické nakladatelství.

[9] Internetová jazyková příručka. Ústav pro jazyk český, v. v. i., Praha. Accessible at: $<$ https : / / prirucka.ujc.cas.cz>.

[10] Internetový slovník současné češtiny. Brno, Lingea. Accessible at: <https : / www . nechybujte.cz/slovnik-soucasne-cestiny/>.

[11] Karlík, P., and Hladká, Z. (2004). Kam s ním (problém stupňování adjektiv). In Život s morfémy. Sborník studií na počest Zdenky Rusínové, pages 73-93. Eds. P. Karlík and J. Pleskalová. Brno, Masarykova univerzita. 
[12] Karlík, P., Nekula, M., and Rusínová, Z. (eds.) (2012). Př́ruční mluvnice češtiny. $2^{\text {nd }}$ revised edition. Praha, Nakladatelství Lidové noviny.

[13] Karlík, P., Nekula, M., and Pleskalová, J. (2017). CzechEncy - Nový encyklopedický slovník češtiny. Accessible at: <https: / / www . czechency . org/>.

[14] Komárek, M., Kořenský, J., Petr, J., and Veselková, J. (eds.) (1986). Mluvnice češtiny 2. Praha, Academia.

[15] Křen, M., Cvrček, V., Čapka, T., Čermáková, A., Hnátková, M., Chlumská, L., Jelínek, T., Kováŕíková, D., Petkevič, V., Procházka, P., Skoumalová, H., Škrabal, M., Truneček, P., Vondřička, P., and Zasina, A. Korpus SYN, verze 7 z 29. 11. 2018. Praha, Ústav Českého národního korpusu FF UK. Accessible at: $\langle$ http : / /www. korpus. cz $>$.

[16] Křen, M., Cvrček, V., Čapka, T., Čermáková, A., Hnátková, M., Chlumská, L., Jelínek, T., Kováŕíková, D., Petkevič, V., Procházka, P., Skoumalová, H., Škrabal, M., Truneček, P., Vondřička, P., and Zasina, A. (2015). SYN2015: reprezentativní korpus psané češtiny. Praha, Ústav Českého národního korpusu FF UK. Accessible at: $<$ http: / / www . korpus . cz >.

[17] Křivan, J. (2012). Komparativ v korpusu: explanace morfematické struktury českého stupňování na základě frekvence tvarů. Slovo a slovesnost, 73(1), pages 13-45.

[18] Panevová, J. (2007). Gradation of adjectives and valency. In Gramatika a korpus. Grammar \& Corpora 2005, pages 197-204. Eds. F. Štícha and J. Šimandl. Praha, Ústav pro jazyk český AV ČR.

[19] Panevová, J. (2008). Povaha stupňování adjektiv (K „nesrovnávacímu“ užití stupňovaných forem). In Iugi Observatione: Zborník z konferencie Jazyk - kultúra - spoločnost', venovanej 80. narodeninám prof. PhDr. L. Ďuroviča, pages 149-156. Ed. S. Ondrejovič. Bratislava, Veda.

[20] Světlá, J. (2016). Stupňování př́davných jmen a př́slovcí. In Kapitoly z koncepce Akademického slovníku současné češtiny, pages 62-63. Eds. P. Kochová and Z. Opavská. Praha, Ústav pro jazyk český AV ČR, v. v. i. Accessible at: <https: / / url. cz/SMMCN>.

[21] Štícha, F. (ed.) (2013). Akademická gramatika současné češtiny. Praha, Academia. 